\title{
Effect of Ramadan fasting on body weight and serum cholesterol in middle aged healthy subjects: An observational trial
}

\author{
Muhammad Salahuddin', Sayed Ashfak Ahmed Hussain ${ }^{2, *}$, Quadri Syeda Ayesha ${ }^{3}$ \\ ${ }^{\mathbf{1}}$ Associate Professor, Dept. of Physiology, College of Medicine, Al Jouf University, Saudi Arabia, ${ }^{2}$ Professor, Dept. of \\ Physiology, Government Medical College, Aurangabad, Maharashtra, ${ }^{3}$ Resident, Dept. of Biochemistry, MGM Medical College, \\ Aurangabad, Maharashtra, India \\ *Corresponding Author: \\ Email: drsayedashfaque@rediffmail.com
}

Received: $7^{\text {th }}$ March, 2018

Accepted: $8^{\text {th }}$ May, 2018

\begin{abstract}
Introduction: There are significant changes in the food habits, sleep and behaviour during Ramadan fasting which may significantly impact the body metabolism. This study evaluated effect of Ramadan fasting on body weight and serum cholesterol among normal healthy subjects.

Materials and Methods: Thirty normal and apparently healthy subjects in the age group of 35 to 65 years and determined to complete full month of fasting during Ramadan were enrolled in the study. The outcome measures: body weight $\&$ serum cholesterol were assessed in all the subjects before and after Ramadan month.

Results: The subjects (age: $45.2 \pm 7.24$ years), underwent a significant decrease in body weight from $60.1 \pm 9.4 \mathrm{~kg}$ to $58.5 \pm 9.2$ $\mathrm{kg}(\mathrm{p}<0.0001)$. Serum cholesterol decreased significantly from $175.7 \pm 24.2 \mathrm{mg} \%$ to $166 \pm 31 \mathrm{mg} \%(\mathrm{p}=0.000327)$.

Conclusion: Based on findings from our study sample, we conclude that Ramadan fasting by middle aged healthy individuals may lead to reduction in body weight and decrease in serum cholesterol.
\end{abstract}

Keywords: Ramadan fasting, Body weight, Serum cholesterol.

\section{Introduction}

Ramadan month fasting from dawn to sunset is obligatory for all healthy adult Muslims. There is a general tendency among the fast observers to become more religious i.e. they perform their daily religious duties with more zest and regularity. The main aim of the fast is not just to abstain from the daily needs and pleasures of life, but to develop will power of the human being so that he is able to control his desires. The fasting period begins from just before "Fajr" (dawn) prayers when the Muslims take a meal called "Saher" and it ends with "Iftar" meal which is consumed immediately after sunset. Then, from sunset to sunrise, the person does not need to abstain from any natural, permitted desire $\&$ follows routine life. ${ }^{1,2}$

There is an additional recommended prayer during Ramadan i.e. Taraweeh which is collectively prayed by most of Muslims. This prayer lasts usually from half an hour to two hours or even more related to quantum of recitation of Quran during the prayer. This involves considerable physical activity. Thus, there are significant alterations in the feeding pattern, sleep cycles and behaviour of the people practising the Ramadan fasting. These lifestyle changes can have significant effects on the body metabolism. However, the directions of these changes have been reported differently in various studies. Some studies reported weight loss during Ramadan, ${ }^{3,4}$ while improvements in lipid levels as well as deterioration in lipid profile has been reported in earlier research studies. ${ }^{5-8}$ This study evaluated effect of Ramadan fasting on body weight and serum cholesterol among normal healthy subjects.

\section{Materials and Methods}

Study Site: Physiology Department at a tertiary care Medical College in Marathwada region of Maharashtra. Thirty normal healthy subjects (age group: 35 to 65 years) with no history of major disease or addictions were included. Informed consent was obtained. After an overnight 10 to 12 hours fasting and around 2 to 5 days prior to Ramadan and from the $3^{\text {rd }}$ to $5^{\text {th }}$ day after the end of Ramadan month, five ml blood sample was taken. CHOD-PAP method was used for serum cholesterol estimation. ${ }^{9}$ Body weight measurements (nearest $0.1 \mathrm{~kg}$ ) were done. Paired t test was used to compare the before and after observations in the same group.

\section{Results}

The mean age of study subjects was found to be $45.2 \pm 7.24$ years.

Table 1: Ramadan fasting effect on body weight \& serum cholesterol levels

\begin{tabular}{|l|c|c|c|c|}
\hline \multicolumn{1}{|c|}{ Parameter } & Before Ramadan & After Ramadan & Difference in means & p value \\
\hline Body weight (kilograms) & $60.1 \pm 9.4$ & $58.5 \pm 9.2$ & -1.6 units & $<0.0001^{*}$ \\
\hline Serum cholesterol (milligram \%) & $175.7 \pm 24.2$ & $166 \pm 31$ & -9.7 units & $0.000327^{*}$ \\
\hline
\end{tabular}

SD: Standard deviation *indicates statistically significant 


\section{Discussion}

Unhealthy lifestyle characterized by unhealthy diet and low physical activity leads to metabolic disturbances like weight gain and altered lipid levels. ${ }^{1}$ Balanced diet \& regular physical exercise are key components in the maintenance of healthy body mass. ${ }^{10}$ In this context, the obligatory fasting in Islam provides an interesting opportunity to reduce food intake and increase physical activity. Although diet varies a lot among individuals during Ramadan, the extensive extra congregational prayers seem to be universally adopted which along with individual prayers contributes to moderate activity levels. Without any doubt, Ramadan fasting is in not about body features but it is a spiritual phenomenon. So, the impact of Ramadan fasting exceeds beyond those that result from following a particular diet. ${ }^{11}$

In line with our results, a systematic literature review by Imtiaz Salim et al ${ }^{12}$ have stated that weight in relation to height, blood levels of fats and arterial blood pressure showed significant improvement among normal healthy subjects after Ramadan fasting. Study by Haghdoost et $\mathrm{al}^{13}$ which evaluated the interaction of activity levels and Ramadan fasting on lipid levels reported a decrease in body weight and serum cholesterol in fasting subjects. They stated that activity levels in isolation cannot explain the improved lipid levels. The dietary changes as well as altered sleep patterns during Ramadan fasting may have contributed to the results. In our earlier published study done in subjects with hypertension, fasting was found to significantly reduce body weight, systolic \& diastolic arterial blood pressure whereas there was no significant change in serum cholesterol. ${ }^{14}$ Mohsin $\mathrm{N}$ et al study results reflect significant lowering in coronary cardiac disease risk score (ten year) \& other cardiovascular risk factors such as weight, BMI and waist circumference in subjects with a previous history of cardiovascular disease after an average of 26 days fasting during the month of Ramadan. ${ }^{15}$

\section{Conclusion}

Based on findings from our study sample, we conclude that Ramadan fasting by middle aged healthy individuals may lead to decrease in body weight and serum cholesterol values.

\section{References}

1. Al Hourani H, Atoum M, Akel S, Hijjawi N, Awawdeh S (2009) Effects of Ramadan Fasting on Some Haematological and Biochemical Parameters. Jordan Journal of Biological Sciences. 2009;2(3):103-108.

2. Mansi K (2007) Study the Effects of Ramadan Fasting on the Serum Glucose and Lipid Profile among Healthy Jordanian Students. American Journal of Applied Sciences. 4(8):565-569.

3. Toda M, Morimoto K. Effects of Ramadan fasting on the health of Muslims. Nippon Eiseigaku Zasshi. 2000;54(4):592-6.
4. Adlouni A, Ghalim N, Benslimane A, Lecerf JM, Saile R. Fasting during Ramadan induces a marked increase in high-density lipoprotein cholesterol and decrease in lowdensity lipoprotein cholesterol. Ann Nutr Metab. 1997;41(4):242-9.

5. Lamine F, Bouguerra R, Jabrane J, et al. Food intake and high density lipoprotein cholesterol levels changes during Ramadan fasting in healthy young subjects. Tunis Med. 2006;84(10):647-50.

6. Afifi ZE. Daily practices, study performance and health during the Ramadan fast. $J R$ Soc Health. 1997;117(4):231-5.

7. Khaled BM, Bendahmane M, Belbraouet S. Ramadan fasting induces modifications of certain serum components in obese women with type 2 diabetes. Saudi Med J. 2006;27(1):23-6.

8. Yarahmadi SH, Larijani B, Bastanhagh MH, et al. Metabolic and clinical effects of Ramadan fasting in patients with type II diabetes. J Coll Physicians Surg Pak. 2003;13(6):329-32.

9. Burtis CA, Ashwood ER, Bruns DE. Tietz Textbook of Clinical Chemistry AND Molecular Diagnostics. Fourth. Elsevier Saunders, Philadelphia;2001.

10. Momen K, Elzouki Y, Gatie J, El-Mansoury M, Tashani A (2007) Effect of Ramadan Fasting on Blood Glucose and Serum Lipid Profiles in Libyan Diabetic Patients. Journal of Science and its Applications. 2007;1(1):14-17.

11. Abdullah Shehab, Abdishakur Abdulle, Awad El Issa, 1 Jassim Al Suwaidi, and Nico Nagelkerke. Favorable Changes in Lipid Profile: The Effects of Fasting after Ramadan. PLoS One. 2012;7(10) e47615. https://doi.org/10.1371/journal.pone.0047615

12. Imtiaz Salim, Jassim Al Suwaidi, Wissam Ghadban, Hani Alkilani, Amar M. Salam. Impact of religious Ramadan fasting on cardiovascular disease: a systematic review of the literature. Cardiology and Vascular Disease: Review. April 2013;29(4):343-354.

13. Haghdoost A A, Poor Ranjbar M. The interaction between physical activity and fasting on the serum lipid profile during Ramadan. Singapore Med J. 2009;50(9):897-901.

14. Salahuddin M, Sayed Ashfak AH, Syed SR, Badaam KM. Effect of Ramadan fasting on body weight, blood pressure and biochemical parameters in middle aged hypertensive subjects: An observational trial. J Clin and Diagn Res. 2014 March;8(3):16-18.

15. Mohsen Nematy, Maryam Alinezhad-Namaghi, Masoud Mahdavi Rashed, Mostafa Mozhdehifard, Seyedeh Sania Sajjadi, Saeed Akhlaghi, et al. Effects of Ramadan fasting on cardiovascular risk factors: a prospective observational study. Nutr J. 2012;11:69. doi: 10.1186/1475-2891-1169.

How to cite this article: Salahuddin $M$, Hussain SAA, Ayesha QS. Effect of Ramadan fasting on body weight and serum cholesterol in middle aged healthy subjects: An observational trial. Ind $\mathrm{J}$ Clin Anat Physiol. 2018;5(3):410-411. 